which is being organized by Mr. J. A. Ratcliffe, will be devoted mainly to a discussion of the following topics: $(a)$ the lowest jonosphere; (b) irregularities and movements in the ionosphere; (c) the ionospheric F2 layer ; $(d)$ the mathematics of wave propagation through the ionosphere. Accommodation can be provided at Cambridge ; application forms, which are obtainable from the offices of the Physical Society, should be returned to the Cavendish Laboratory, Cambridge, before August 16.

The seventh Rutherford Lecture of the Physical Society will be delivered by Prof. P. M. S. Blackett on November 26 in the Lecture Theatre, Science Museum, Exhibition Road, London, S.W.7, at 5 p.m. His subject will be "The Organization of Scientific Discovery". At a Science Meeting of the Society to be held on November 5, at 5 p.m., in the Lecture Room, Royal Astronomical Society, Burlington House, London, W.I, the Duddell Lecture will be delivered by Prof. A. C. B. Lovell on "The Development and Use of Large Radio Telescopes", and the Charles Vernon Boys Lecture will be given by Dr. J. S. Courtney-Pratt on "Some New Methods of Fast Photography". These lectures are open to non-members of the Society.

\section{United States Fellowships for British Scientists}

Nine fellowships for research in American institutions have been awarded to British scientists under a technical assistance programme sponsored by the United States Foreign Operations Administration. This will bring to eleven the number of fellowships awarded to British scientists since the inception last year of this programme, which provides for about a hundred and fifty younger scientists from fourteen Western European countries to undertake advanced study at American universities and research institutions, about twenty-five of the total being from the United Kingdom. The latest British awards, which have been made by the National Academy of Sciences, Washington, D.C., on the nomination of the Royal Society of London, are to the-following for study at the institutions indicated: Dr. D. R. Bowsher (assistant lecturer in anatomy, University of Liverpool), Harvard Medical School; I. Castillejo (lecturer in physics, University College, London), Cornell University; Dr. B. R. Coles (lecturer in metal physics, Imperial College of Science and Technology, London), Carnegie Institute of Technology; Dr. F. M. Dean (lecturer in organic chemistry, University of Liverpool), University of California; Dr. R. F. Evans (Chemical Research Laboratory, Teddington), Purdue University; Dr. V. A. Knivett (Chemical Research Laboratory, Teddington), University of Wisconsin; A. G. Milnes (Royal Aircraft Establishment, Farnborough), United States Naval Ordnance Laboratory, Silver Spring, Maryland; Dr. J. Owen (Magdalen College, Oxford), University of California ; and Dr. E. M. Thain (Lister Institute of Preventive Medicine, London), University of California.

\section{Heriot-Watt College, Edinburgh : Fellowships}

HoNorary fellowship of the Heriot-Watt College, Edinburgh, has been conferred on the following, all of whom are former students of the College: Mr. C. Batey, printer to the University of Oxford; $\mathrm{Mr}$. R. C. M. Dickson, Scottish representative director of Boots Pure Drug Co., Ltd.; Mr. W. B. Laing, general manager of Bruce Peebles and Co., Ltd., Edinburgh; Sir William Paterson, chairman and managing director of the Paterson Engineering Co.,
Ltd., London; and Dr. Rameshawr P. Sinha, principal of Dhanbad School of Mines, India. Fellowships by thesis have been awarded to the following : Ralph A. Aitken (enzymolysis of cell-wall materials with special reference to the malting process), and Sailendra N. Ghosh (new network analyser).

\section{Society for Applied Bacteriology: Officers}

THE following have been elected officers of the Society for Applied Bacteriology : President, Mr. S. B. Thomas; Secretary, Mr. G. Sykes (Boots Pure Drug Co., Ltd., Microbiology Division, Nottingham); Treasurer, Mr. C. S. Miles ; Editors, Dr. S. E. Jacobs and Dr. L. F. L. Clegg; Publications Manager, Mr. E. A. Whitlock; Advertising Manager, Mr. E. J. Mann; Ordinary Members of the Committee, Dr. L. A. Allen, Mr. K. R. Butlin, Mr. J. W. Egdell, Dr. L. D. Galloway, Dr. A. Hirsch, Dr. M. Ingram, Mr. D. A. McKenzie, Mrs. A. C. Stirling and Dr. Helen R. B. White.

\section{Announcements}

The Scientific Instrument Manufacturers' Association has elected as its president for 1954-55 Mr. C. E. T. Cridland, chairman and managing director of a group of companies which includes Aldis Brothers, Ltd., of Birmingham. Mr. Cridland was trained as an electrical engineer, and has been connected with engineering industry all his life, particularly electrical and aeronautical engineering.

ThE Committee representing the Royal Society and the Armourers and Brasiers' Company has appointed Mr. K. E. Puttick to be Armourers and Brasiers' Company Research Fellow from October 1, 1954 , to work at the H. H. Wills Physical Laboratory, University of Bristol, on the structure and deformation of pearlite.

THE Council of the Royal Society has awarded Mr. and Mrs. John Jaffe Donation Studentships from October 1, 1954, to the following: Dr. Eileen N. Richardson, to work at the Physical Chemistry Laboratory, University of Oxford, on the kinetics of bromination of selected aromatic compounds; and Mr. A. Korner, to work at the Department of Biochemistry, University of Cambridge, on the influence of hormones on metabolism.

AN award under the Royal Society and Nuffield Foundation Commonwealth Bursaries Scheme together with financial support from the Board of the Dairy Research Institute, Palmerston North, New Zealand, has been made to Dr. S. Y. Thompson, of the National Institute for Research in Dairying, Reading, to enable him to visit the former Institute in 1955 in order to study factors controlling the vitamin A potency of New Zealand butter.

THE University of Padua is offering a Gabriella Zuccari scholarship of 300,000 lire for research of at least six months duration at the Zoological Station, Naples, during the academic year 1954-55. The scholarship is open to any person who wishes to undertake research in zoology, comparative anatomy, physiology or embryology. Application forms (to be returned by October 30) can be obtained from the Secretariat of the University of Padua.

Erratum. In the communication of May 15, p. 956, on the "Life-history of the Rat Lung-worm and its Migration through the Brain of its Host", by Dr. M. Josephine Mackerras and Miss Dorothea F. Sandars, the two illustrations should be interchanged. 